دورية علمية محكمة. كلية الآداب- جامعة أسوان أكتوبر 9 ب ب

\title{
Osiris in the third intermediate period
}

\author{
8)(9)
}

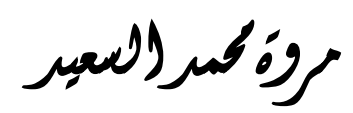




\section{Introduction:}

The translation of the ancient texts developed through all the Pharonic periods, and splited into old, middle and late Egyptian. Religious texts are a fundamental part of any pre-modern culture. It splites to mortuary texts which related to after death, and texts dedicated to the deities, which is through life time like oracle amuletic decrees. The mortuary texts divided into two parts: texts dedicated from the deceased to the deity, and texts dedicated from the deity to the deceased. The editing of the mortal texts has developed along the old, middle and new kingdom till the Ptolemaic period. Mortal texts reflect the feeling of the deceased to his deity through his life style. For example, an average family uses cheap stuff and asked the deity in the netherworld modest requests. While luxuries family used expensive materials like "wschaptie" statues with large numbers to help them in "iyaro" fields. In New kingdom they developed from coffin texts to papyrus texts which preserved in the deceased's coffin.

\section{Conception of mortal texts:}

The function of mortal texts was to guarantee a happy life in the netherworld through the praise from the deceased to the deity. Concept of the mortuary texts: the editing of the texts expresses the thoughts of the society in a certain period, clears the identity of the individual, and defines the social situation in which it is taking place. Numerous manuscripts of the 4th century in particular include materials assembled from the so-called "Osiris liturgies", this funerary texts aimed to save the deceased from the examiners of the dead $^{1}$. The aim of the deceased from those texts was a safe entry into eternal life and to provide a secure passage through the underworld and resurrection in the world of eternity ${ }^{2}$. The practices of the pyramid texts (PT) became available to non-royal men and women in the appearance of the book of the dead (BD). At the beginning of the N.K. spells were no longer confined to large and expensive tombs or

1- Emily Christine Cooper Cole: Interpretation and Authority: the Social Functions of Translation in Ancient Egypt, University of California, Los Angeles, 2015, P. 1325.

2- Uranić, I.: Book of the Dead, Papyrus Zagreb 601, Studien zur Altägyptischen Kultur, Bd. 33, Helmut Buske Verlag GmbH (2005), p. 357-371. 


\section{دورية علمية محكمة كلية الآداب- جامعة أسوان أكتوبر 9 ب ب r}

coffins, but were placed on movable and more affordable linen or papyri ${ }^{1}$.

\section{Petitions from the deceased:}

Those petitions were mortal texts from the recently deceased to the deity typically for assistance with problems in the netherworld. They are known from the O.K. through the late period. They have been reserved upon ceramic vessels, stone stelae, papyrus and linen. Those letters illuminate the relationship between the living and the dead, and expand upon our knowledge of mortuary culture and popular religious practices in ancient Egypt.

\section{Components of the petitions:}

1- Address: letters can address from either male or female directly or indirectly, the address may include names, titles and filiation.

2- Greetings of the petitions:" Osiris xnty-imntyw makes for you millions of years". When a greeting is present in a letter, it takes the form of an offering formula, well-wishing, or other invocation.

3- Statement of the problem: "you know he said to me, I'll accuse you and your children"2.

\section{Ritual texts:}

Whether the ritual texts composed for the deity or the deceased, originally the text is adapted for the benefit of both of them. Sminis the son of Petemestous who was a priest served in the cults of Osiris and other deities at Thebes during the fourth century BC, buried with him manuscript preserves a series of offering formulas. Some are addressed to Osiris, others written for deceased people ${ }^{3}$. The funerary

1- Cole, E.: the gendered individual in funerary papyri of the Ptolemaic and Roman periods, Jstor, American research center in Egypt, v.49, 2013, p.205-218.

2-Troche, J.: Letters to the dead, UCLA, encyclopedia of Egypt, V.1(1), 2018, P.114.

3- Smith, M.: Whose Ritual? Osirian Texts and Texts written for the deceased in $P$. BM EA 10209: A case study, in: Liturgical Texts for Osiris and the deceased in late period and Greco-Roman Egypt, proceedings of the colloquiums at N.Y. (ISAW), 6 May 2011, and Freudenstadt, 18-21 July 2012, Wiesbaden, 2015, P. 161. 
papyri in the 21 dynasty were distinguished in the quantitative of the texts as a special phase in funerary papyri ${ }^{1}$.

\section{Funerary cult in the TIP:}

During the late Ramesside period and the third intermediate period, the mortuary landscape and funerary cult changed drastically. The disorder recorded in the late N.K. especially in the Theban necropolis produced a sense of insecurity that was mirrored in burial customs. Basically the realization that burials didn't remain undisturbed forever affected perception and the intimate meaning of burial practices and grave goods. The tomb itself no longer represented a secure place for the dead as conceived in the early N.K. so it resulted the mass burials in cashes in which we found the papyri of the deceased the subject of this search. As a result of this significant change in conception the burials turned from the tomb to the coffin as the new protective house of the dead ${ }^{2}$.

\section{Late Egyptian grammer:}

The language of ancient Egypt during the N.K. and the third intermediate period is attested in written form in a large array of literary and nonliterary genres, mainly in the hieratic script on papyri and ostraca. Late Egyptian distinguished from middle Egyptian by being more analytical in character, and it is more clearly in the articulation of sentences. It is more time oriented in its system of grammatical tenses than the system of classical Egyptian. The development of late Egyptian can be divided into three major phrases; 1 - from the $18^{\text {th }}$ dynasty to Ramses II. 2- from Merenptah to the $21^{\text {th }}$ dynasty. 3 - from the 22 to the 25 dynasties. But late Egyptian was never used in all domains, literary texts were written in earlier Egyptian remained in use down to Ptolemaic and Roman times and was employed for royal and religious texts. This means that the papyri of this search were written in the late period but with some

1- Tarasenko, M.: The vignettes of the book of the dead chapter 17 during the third intermediate period (21-22 dynasties), studien zur altagyptischen kultur,

Bd.41,2012, helmut buske verlag gmbh, p.379-394.

2- Miniaci, G.: the case of the third intermediate period 'shabti-maker' of the Amun domain diamun/ padiamun and the change in conception of shabti statuettes, jstor, v.100, sage publications, 2014, p.269. 
middle Egyptian rules. There are differences between classical and late Egyptian, for example in a religious ritual letter that has been transmitted in two versions, we can notice that the late letter has definite article pA, a relative clause introduced by nty-iw (analytic strategy) and aHAwty. While the classical letter has no definite article, it employs nfr-Hr (synthetic strategy) and containes TAi instead of aHAwty.

For example;

1- fAi-a TAi nTrw "O, raised of arm, male of the gods". Classical Egyptian.

2- pA nty iw Drt.t =f fAi, pA aHAwty n nTrw ."O, the one whose arm is raised, the male of the gods". Late Egyptian ${ }^{1}$.

\section{Basics of late Egyptian:}

Late Egyptian underwent many phonological changes as it led to a new grammar and a comprehensive dictionary.

1- Late Egyptians scribes might use special notations, like the doubling of the sign 2 rmi 'cry'. Or ad hoc spellings, especially in the status pronominales to indicate the retention of the final consonant 管। them'.

2- Some words replaced older ones such as ptr 'see' which became the generic verb of seeing in late Egyptian instead of the earlier mAA, and Sri 'son' instead of earlier Egyptian sA, and irm 'with' instead of earlier Hna.

3- The endings for the feminine and plural are no longer systematically written and one can observe numerous inconsistencies for instance masculine nouns written with a ' $\mathrm{t}$ ' ending,

1- Winand, J.: Late Egyptian, UCLA, encyclopedia of Egyptology, university of California, Los Angeles, 2018, P.1-32. 
4- When a personal pronoun points to a neutral referent, the masculine form is preferred in late Egyptian in contrast to middle Egyptian. where the feminine was consistently used.

5- The use of dependent pronouns is more limited in late Egyptian than in middle Egyptian.

6- Late Egyptian has a number of interrogative words that can be used either adjectivally or pronominally like nim 'who', iT 'what', wr 'how many' and Tnw 'where'.

7- Late Egyptian displays changes that wrought significant diachronic consequences in the later stages of the language, as it experienced many developments in the reduction of the rich set of adjectival forms and of the passive tenses and emergence of full-fledged emphatic tenses ${ }^{1}$.

\section{The twenty first dynasty of Egypt:}

The 21th dynasty of Egypt is usually classified as the first dynasty of the TIP lasting from $1069 \mathrm{Bc}-945 \mathrm{Bc}$. After the reign of Ramses III, a long slow decline of royal power in Egypt followed. The pharaohs of the 21th dynasty ruled from Tanis, but were mostly active only in lower Egypt which they controlled. This dynasty is described as "tanite". Because it's political capital was based at Tanis. Meanwhile the high priests of Amon at Thebes effectively ruled middle and Upper Egypt in all but just in name only. According to Manetho, the $21^{\text {st }}$ can be seen to have been transmitted with a relatively high degree of accuracy ${ }^{2}$.

\section{The Hieratic handwriting and its characteristics:}

Writing is the first phase in human communication, but writing is symbols not sounds, but the ancient Egyptian knows that the alphabetical system is a principle, not a number. As long as the alphabetical principle exists, the number of symbols is of secondary importance, which means that you can write the same symbols with different determinative to give different meanings. In the hieratic writing, the ancient Egyptian made shorthand in the general structure

1- Winand, J.: ibid.

2- Kitchen, K.: the third intermediate period in Egypt (1100-650 BC), Warminster England, 1973, p.1-457. 
of the symbol for ease, speed and smoothness of writing on the papyri. The importance of the hieratic handwriting represented in it recorded all what we knew about the ancient civilization, culture, science, social aspects, economic, legal, and the traditions and development of ancient Egyptian society throughout the ages ${ }^{1}$. The hieratic stages divided into old, middle and late hieratic. Hieratic was the most useful handwriting, and the pupils were training on it in writing schools using ostracon because it was easily to be found in the quarry fragments, and the papyri was expensive so it was used in important manuscript only like financial, religious, magic, scientific and literature texts ${ }^{2}$.

\section{The reasons that led to the emergence of the hieratic writing:}

The long period of time in which the ancient Egyptian language survived led to the emergence of multiple linguistic stages. It also led to the appearance of linear stages, commensurate with the conditions of the times and the requirements of the language stages in its times. The late Egyptian began from Akhenaten till the beginning of the 25 th dynasty. and the papyri of this search is concerning about the period of the late of the 20th dynasty till the beginning of the 21th dynasty ${ }^{3}$.

\section{The beginning of the emergence of the Hieratic line:}

The hieroglyphic writing is the full form of the sign, so it was necessary to look for a simplest form of writing, and it was the hieratic. The oldest hieratic sign appeared since the early dynastic era exactly at the $1^{\text {st }}$ dynasty, and almost simultaneously with the hieroglyphic line. Hieratic used to be written op papyri and ostraca feather or woven pen. It was called "hiratikos" because it's relativity to priesthood, as it was used in writing religious and literature

$$
\begin{aligned}
& \text { 1- عبد الرحمن ابوزيد: سمات وأسس الذط الهير/طبقى، الطبعه الأولى، القاهره } 7 \text { اـr، ص } \\
& \text {. } \\
& \text { '- نيقو لا جريمال: تاريخ مصر القديمه، ترجمة ماهر جويجاتى، الطبعه الثانيه، دار الفكر }
\end{aligned}
$$

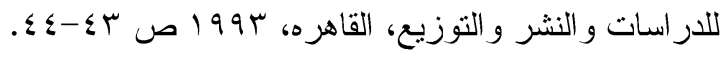

$$
\begin{aligned}
& \text { r - عبد الرحمن ابوزيد: نفس المرجع السابق. }
\end{aligned}
$$


manuscripts only. There is a difference between term "line" and "writing", the term line means the craft and technology themselves, while the term writing means the civilizational and cultural concept of the written subject ${ }^{1}$.

\section{Stages of hieratic:}

The hieratic line went through several stages of development and the hieratic signs were at their beginning closer to the hieroglyphic signs, characterized by preservation and caution, avoiding extreme abbreviation and commitment to preserving the main feature of the sign. Then the writing began to evolve from one stage to another. and every time or stage an ineffective part is deleted from the mark or its modification is in its shape until it reached a difficult stage to be identified and can hardly be linked between it and the original hieroglyphic sign. then it can be identified only by realizing and understanding the various stages of development and tracking what is abbreviated during it. The hieratic stages could be divided into archaic hieratic, old hieratic, middle hieratic, new hieratic and late hieratic.

\section{Chapter one:}

\subsection{OSIRIS (wsir):}

Osiris was considered from the important deities because of his impersonal attributes and power. The significance of Osiris for the Egyptians lay in what he personally had done through his life, death and resurrection. To understand why Osiris was so significant, we have to know that the Egyptians didn't divide the person into a corruptible body and immortal soul ${ }^{2}$. Osiris had a role in death for generation and further life. This religious concept explains the influence of the solar cult in eternal life and rejuvenation. To realize Osiris's importance as well, Diodorus Siculus identified each Egyptian deity with its Greek counterpart in his account of the

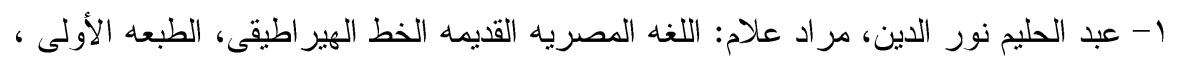

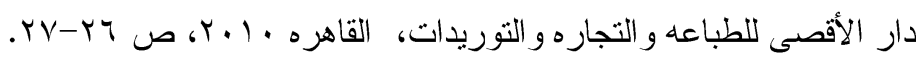

2- Smith, M.: Osiris and the deceased, UCLA, encyclopedia of Egyptology 1(1), Los Angeles, 2008, p.1-8. 
Heliopolitan system giving to Osiris and Isis a central and foremost place within the Egyptian system. Plutarch also systematically identified Osiris with the Nile ${ }^{1}$. Egyptian religion would have had more influence in the early period than on main land Greece, to the extent that Minoan religion held some beliefs in the afterlife for the individual influenced by Egyptian tradition. Minoans was parallel for Osiris in Egypt, it is supposed that dying and rising god of Crete could also be a reflection of the dying and rising god of Egypt (Osiris). Osiris also identified with the Greek Dionysus, and this identification between them would constitute a study in its own right $^{2}$. The cult of Osiris became increasingly important from the TIP and witnessed by several shrines at Karnak. Several chapels were dedicated to specific forms of Osiris, such as "Osiris wennefer, lord of nourishment" and "Osiris who resides in the persea tree". The buildings are inscribed with the names of the ruling pharaohs and divine adoratrices ${ }^{3}$. The worship of Osiris continued till the late period in addition to its relation with Amun. There is a temple at Hibis was dedicated to "Amun lord of hibis", and several rooms in it was dedicated to Osiris, this temple contains approximately 700 representations of divine statues of both gods. This temple also has sepAt (geographic-religious entities) presented an overview of the active cults of the time each sepAt takes a form of Osiris (Pl.5) . Also, a large part of the Egyptian pantheon was brought together on the walls of the cella of Amun temple at Hibis wherein the gods of Egypt were gathered and the yearly rebirth of Osiris celebrated. Although this scene is provided by Ptolemaic temple-reliefs, which proves that the cult of Osiris extended to the Ptolemaic period ${ }^{5}$. During the $27^{\text {th }}$ dynasty a mudbrick temple dedicated to Osiris-iw was built in the southern part of the kharga oasis. Late period popularity of Isis and Osiris manifested in the grand Osirian festivals

1- Vincent, T.: Isis and Demeter of divine motherhood, jstor, American research center in Egypt, v.28, 1991, p. 187-200.

2- Vincent, T.: ibidem.

3- Zivie-Coche, C.: Late Period Temples. In Willeke Wendrich, UCLA, encyclopedia of Egyptology, Los Angeles, 2008, p. 8.

4- ibid: p. 7.

5- ibid: p. 8. 
held in Khoiak month to celebrate the rebirth of the deceased god Osiris ${ }^{1}$. Osiris was connected to the pharaoh, through the fact that the pharaoh's rule was based on the gifts of eternal life anx $f$, wellbeing

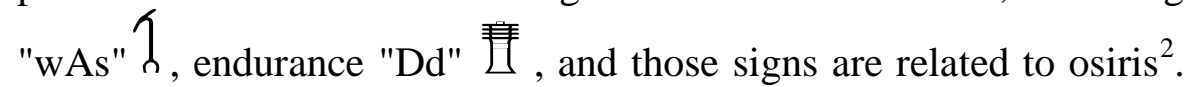
The rule of Osiris as a deity of eternity developed since the new kingdom in both textually and pictorially ways, and it can be shown in spell 125 in the book of the dead as Osiris was the presiding judge ${ }^{3}$.

\section{Forms of Osiris:}

In the earlier periods of Egypt, people worshipped objects or emblems as fetishes, and then people became more sophisticated and worshipped animals instead. By early historic times they were worshipping human forms. This evolutionary history allowed early Egyptologists to read the various forms of deities as an amalgam of different phases in a history of depiction, where human, humananimal, animal, and objects were worshipped. Osiris attested as principal deity in more than one town. and he was depicted like a man, wrapped body, and wearing ostrich plumes headdress ${ }^{4}$. Osiris usually depicted in a human form in mummy form with white skin like the color of the embalming coil, or black skin as a symbol of Nile silt and fertility ${ }^{5}$. May be the meaning of his name means the "the place of the eye", that's why he is represented with the eye sign. In early times, Osiris merged with anDty the deity of fertility of Busiris city and took the insignia symbols the crook and the sceptre from this city. He symbolized his appearance with wheat where he

1- ibid: p.10.

2- Kuhlmann, K.: Throne, UCLA, encyclopedia of Egyptology, 2011, p. 6.

3- Donald, R.: the oxford encyclopedia of ancient Egypt, v.I, oxford press, 2001, p.618.

4- Quirke, S.: Exploring religion in ancient Egypt, Oxford, UK, first edition, 2015, p.28.

$$
\begin{aligned}
& \text { 0- عبد الحليم نور الدين: الديانه المصريه القيمه، ج ( (المعبودات)، القاهره، الطبعه r، }
\end{aligned}
$$

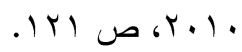


was buried in the ground (burial) then the seed germinates again (Resurrection). There was a relationship between the Nile donor of life and the deity, that's why the Nile was called the flow of Osiris. Osiris inherited the verdict from his father $\mathrm{Gb}$, and got the epithet wn-nfr "the good creature". A tree was planted beside the coffin to indicate that the deity was resurrection from the death. He was the night image of the sun and he connected with the moon, so the moon's phases were indicative of God's death and resurrection. The color of his skin was symbolic, it was white like the mummy roll or black for its association with the netherworld or green as an evidence of resurrection ${ }^{1}$.

Plants sprout from a mummy in a visual image reminiscent of the seeded 'grain-Osiris' figures which were sometimes placed in Egyptian tombs. Coffin detail, Fitzwilliam

Museum, Cambridge.

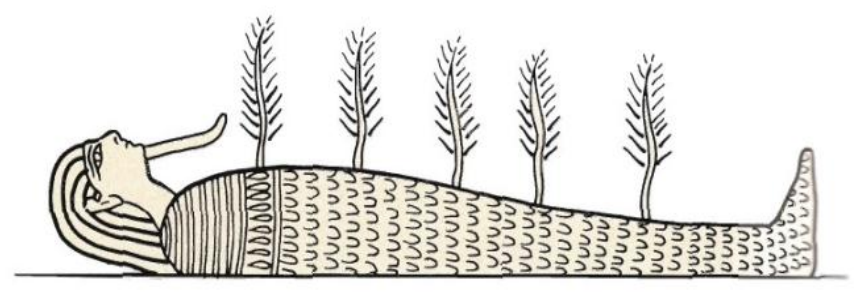

Form of Osiris ${ }^{2}$

We can see here that Osiris is symbolizing to the fertility of the soil and resurrection of the wheat seeds.

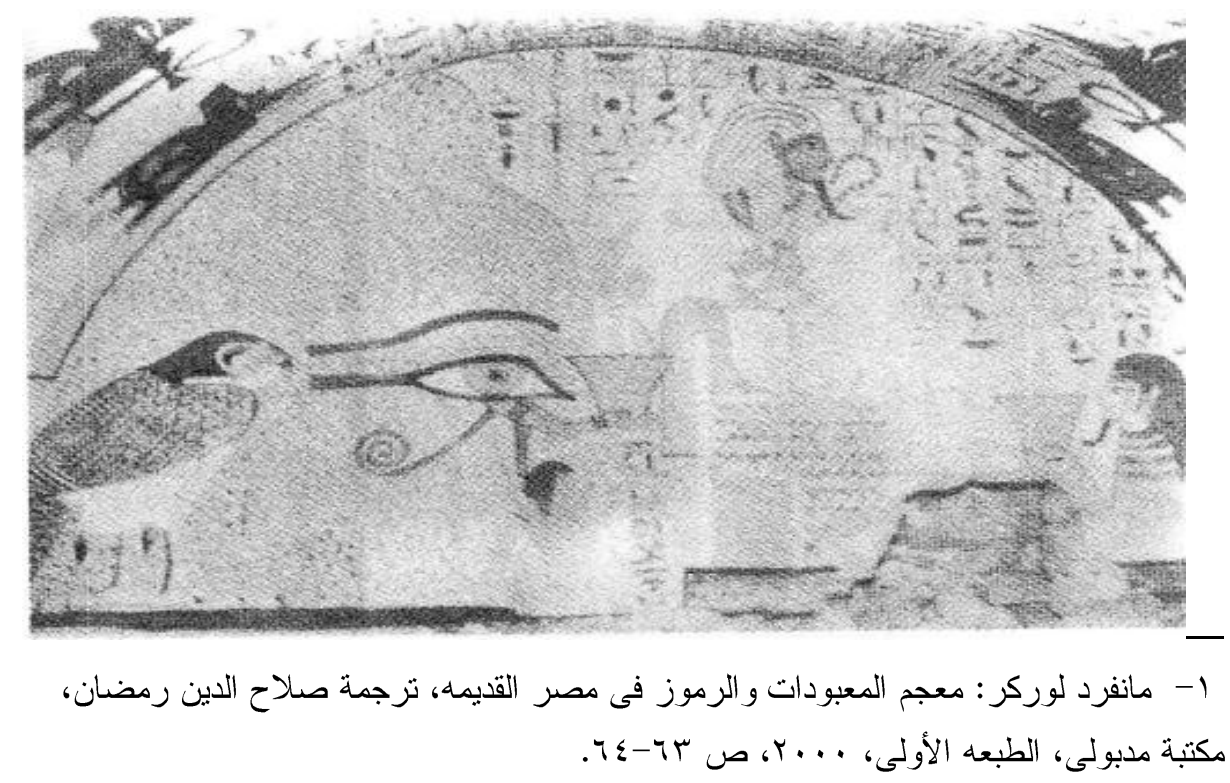

2- Wilkinson, R.: the complete gods and goddesses of ancient Egypt, New York, 2003, p.122. 
A vignette depicting Osiris sitting in front of a mountain, and the deceased kneeling behind the deity's throne under the wDAt eye. Bashdo tomb, $20^{\text {th }}$ dynasty, Deir el-madina,Thebes ${ }^{1}$.

\subsection{Osiris ability to renew youth:}

The pyramid texts tell us that Osiris was the only god who carried within him the seed of his death and resurrection in the shape of a youth. Osiris died but he was reborn and rejuvenated with the flood and the water in the flood which had been emanated from Osiris. So that Egyptians considered the flood the actual exudations of Osiris corpse and the inundation was seen as the liquids running from Osiris decaying corpse.

\section{Osiris symbols:}

舟

Those 3 signs symbolizes to life, longevity and strength. By the new kingdom, the Dd became the symbol of Osiris. The scepter wAs 'the symbol of strength' submit to Osiris 'the deity of life' to increase his power. 'I'm coming to you by order of $\mathrm{Gb}$ to increase your strength against the enemies'.

?A

Those signs symbolizes to command and renew youth, and they were the emblems of Osiris submitted to him to award him body safe. Osiris submits a statement of his property to his son Horus to submit it to his heritage "the ruling pharaoh". Osiris and Isis take one 'areous' as they ruled the country together since it was united ${ }^{2}$.

善

This Dd pole is a symbol of god Osiris, it refers to stability and permanence and it probably represent the backbone of the human, but the scientists didn't determine exactly what it is till now. This Dd is a symbol of Osiris resurrection, this was proven through the vignettes

$$
\begin{aligned}
& \text { ' - م مانفرد لوركر: نفس المرجع السابق. } \\
& \text { r- سيلفى كوفيل: قر ابين الآلهه فى مصر القديمه، ترجمة سهير لطف اله، مطبعة بى إتشروا، }
\end{aligned}
$$

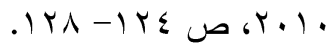


of the ritual of indwelling the Dd pole. This Dd was the main axis in those vignettes as a symbol of resurrection ${ }^{1}$.

\subsection{The new role of Osiris in the N.K. and TIP:}

At the beginning of the O.K. the funerary texts were dedicated to Anubis, then it began to dedicate to Osiris from the late 5 dynasty and beginning of the 6 dynasty, then Osiris became the god of the eternity in CT in the M.K. and BT in the N.K. then he got his amulets and got mentioned in the spells and protective texts in the late period ${ }^{2}$. Osiris had a new role since the N.K. onwards, as his image of resurrection had changed through his incorporation with the sun god during his night journey to the kingdom of Osiris. Ra himself became a bA with whom Osiris combined every night, and was totally penetrated by his light. So that he would be capable of self-resurrection and selfrejuvenation. Osiris granted a successful birth, rejuvenation and victory over death ${ }^{3}$. Osiris also depicted in the vignettes of the Amduat book on the $21^{\text {st }}$ dynasty coffins, as he was depicted in the seventh hour in a scene of a god striking an enemy in front of Osiris, and depicted in the twelfth hour in the eastern horizon with the gods Shu and Khepri, and depicted in the tenth hour with the crown of upper Egypt and the was-scepter ${ }^{4}$. Besides, by the rule of Ramsses IV Osiris united with the Nile, as Osiris's life is the inundation and his death is the drought ${ }^{5}$. Small chapels dedicated to the funerary god Osiris appeared at Karnak during the TIP, one of these chapels called "wsir-heoA-djet" (Osiris, lord of eternity) ${ }^{6}$. Osiris and Amun had

$$
\begin{aligned}
& \text { '- عبد الحليم نور الدين: الديانه المصريه القديمه، ج ' (المعبودات)، القاهره، الطبعه r.، } \\
& \text {. . }
\end{aligned}
$$

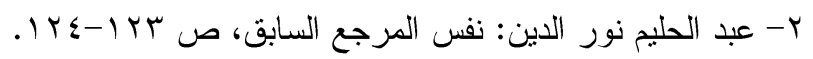

3- Shoaib, W.: Aspects of rnpy in Ancient Egyptian texts, Jstor, V.48, 2012, P.191.

4- cássio de araújo Duarte: The Amduat on the 21st dynasty coffins, in: proceedings first Vatican coffin conference,19-22 June, v.1, 2013, p.138.

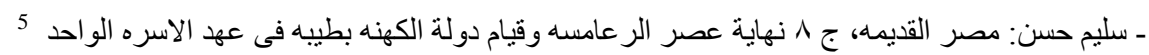

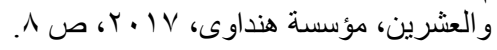

6- Sullivan, E.: Karnak: Development of the temple of Amun-Ra, UCLA, Encyclopedia of Egyptology, 2010, p. 18. 


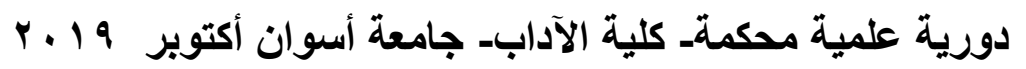

designations reflects their inexhaustible diversity since the new kingdom ${ }^{1}$.

\subsection{Osirian texts:}

Osirian texts mean that this text was used in the cult of Osiris. We can recognize the Osirian text through;

1- The title which stating that it was employed in the deity's cult in a specific temple.

2- Title of a deceased like 'spell for doing such thing for a man in the deity's domain'.

3- Statement addressed specifically to the deceased that make a clear distinction between him and Osiris.

4- The words of the texts are addressed or relate specifically to Osiris, or mention some of the titles or names of Osiris. And this is very clear in the papyrus of this research as Osiris was mentioned here with a weird name ibk in the end of the $20^{\text {th }}$ dynasty and the beginning of the $21^{\text {th }}$ dynasty. And it is worthy to say that this weird name of Osiris that mentioned here is rarely found in other papyrus, as Osiris was mentioned by his name wsir in most papyrus till the Greco-Roman

period.

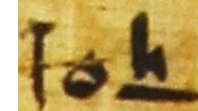

hieratic in a papyri from the Ptolemaic period ${ }^{2}$.

\subsection{Osirian epithets and names:}

Epithets applied to Egyptian deities attests to the complex and diverse nature of Egyptian gods. Epithets outline a deity's character describe his physical appearance and attributes and give information about his cult, it is usually follow the deity name. there are two kinds of epithets, "personal epithets" which identifies a unique aspect of the deity's personality, and "situational epithets" that refers to a particular situation or activity. Egyptian deities including Osiris carried epithets that give information about their nature, forms of manifestation, spheres of

1- Budde, D.: Epithets, Divine, UCLA, encyclopedia of Egyptology, 2011, p.5.

2- Smith, M.: op cit. 
influence, genealogical relations and connections with particular locations ${ }^{1}$. Through the development of the Osirian epithets, Osiris got many epithets expressing his nature and function as the dying and eternally reborn god. He worshipped as nb-anx "lord of life", wrD-ib "weary of heart", rs-wDA "who makes up complete" and nb-nHH, HQA-Dt "master of the course of time" ${ }^{2}$. In the late $12^{\text {th }}$ dynasty, in the Fayoum, a specific Osirian epithet was created; ity Hry ib tA S 'Osiris the sovereign who resides in the land of the lake'. and he appeared also in offering formulas of monuments that belonged to private citizens of the period. The cult of Osiris-ity survived and prospered till the Ptolemaic and roman periods ${ }^{3}$. There is also some epithets used during the Ptolemaic period like wsir xnty imnt nTr aA nb Ab "osir who presides in the west, the great deity, master of Abydos ${ }^{4}$, Wsir nb anx "master of life" and wsir wAD wp-wA.wt "osir the green" from Osiris epithets which mentioned in the spells of the pyramid texts is wsir p Any "Osiris the baboon" ${ }^{6}$. There is a papyrus in Zagreb museum dedicated to the man named Idjedtu-Khonsu-kheper, the Wabpriest of Amon, The text dates to the third Intermediate Period, (as to calligraphic style about $70 \%$ of hieratic signs of this manuscript are comparable to papyri from 18-21 dynasties), Osiris was mentioned in this papyri as wsir wab $\mathrm{n}$ imn 'Osiris the wab priest of Amun', he

1- Budde, D.: Epithets, Divine, UCLA, encyclopedia of Egyptology, 2011, p.1.

2- ibid, p.8.

3- Zecchi, M.: theophoric and basilophoric personal names in the fayum in the middle and new kingdoms, in: Archéologie -Histoire-Religion, Actes du sixième colloque international Montpellier, 26-28 Octobre 2016, Wiesbaden, 2018, P.35.

4- Vuilleumier, S.: un ritual osirien en faveur de particuliers al'epoque ptolemaique, papyrus Princeton pharaonic roll 10, Wiesbaden, 2016, p.260.

5- Vuilleumier, S.: ibid, p.319.

6- Koenraad, D., et al: Hieratic, Demotic and Greek Studies and Text editions, Of Making Many Books There Is No End, Papyrologica Lugduno-Batava, Institutum Papyrologicum Universitatis Lugduno-Batavae, volumen XXXIV, 2018, P.109. 
mentioned with his name wsir

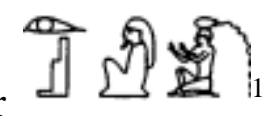
name of the god Osiris written with the sun-determinative during the19-

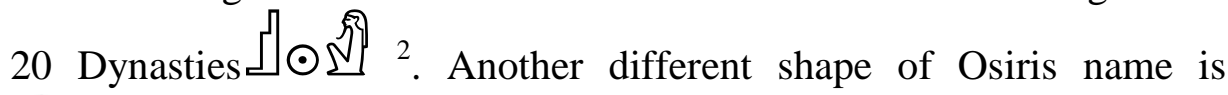
$\overbrace{\text { which is found in the same hieratic papyri in Zagreb museum }}^{3}$.

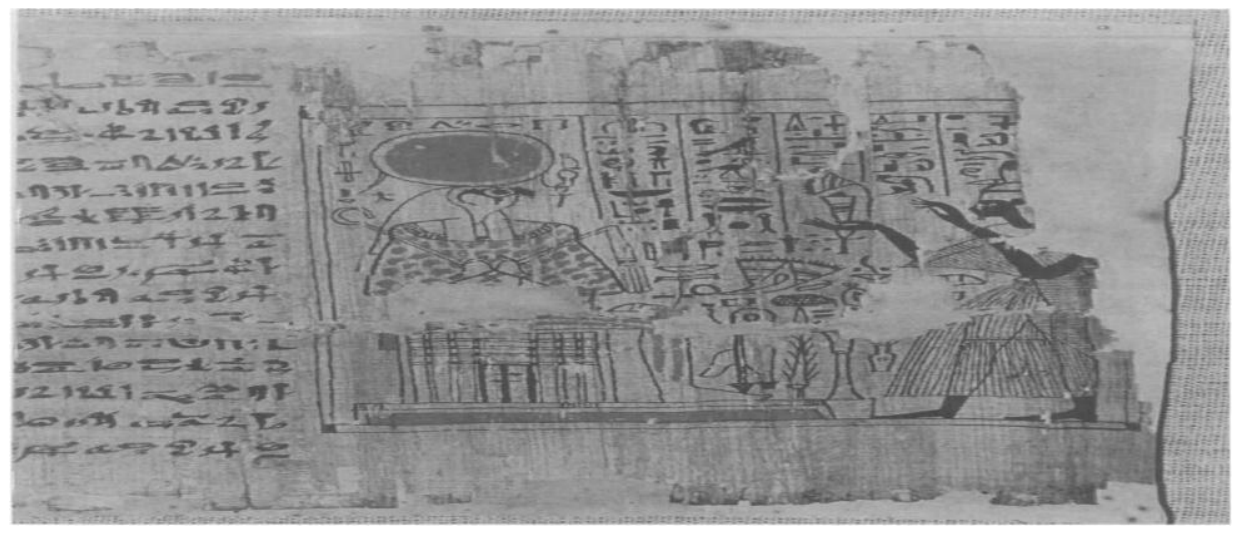

Papyrus Zagreb $601^{4}$

Wsir written in the second and forth row from the right as

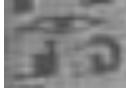
等连 and

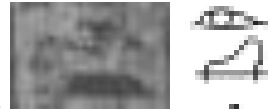

There is a wooden box painted hieroglyphic and carved hieratic inscriptions preserved in the Egyptian museum, this box is linked to a transitional phase in burial customs of the third intermediate period, amongst the inscriptions is the name of the deity Osiris with its normal signs

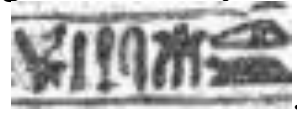

1-Uranić, I.: Book of the Dead, Papyrus Zagreb 601, Studien zur Altägyptischen Kultur, Bd. 33, Helmut Buske Verlag GmbH (2005), p. 357-371.

2- Wb: I, p.359.

3- Uranić, I.: op cit, p. 359.

4- ibid: p. 28. 
maker/priest ${ }^{1}$. Another transcription of the name of Osiris foll the third intermediate period ${ }^{2}$.

It can be noticed here that Osiris was mentioned here by his regular name wsir, even in the late and Ptolemaic periods, which prove that the epithet of Osiris in the papyrus of this search is really weird, and even may be didn't mention in other papyrus. There are two papyri suggested that they are dating to the first half of the TIP through the script and especially the owner's titles, they were donated to the Bodleian library under the name of Ms. Egypt.d.10 (P) and Ms. Egypt.d.11 (P), and they are all remains of the book of the dead. The first one is related to a chantress of Amun named djed-khons-iw.s-anx. It is consists of seven fragments written in black ink. The second one consists of five fragments and the owner is identified as "wsir Smai.t $\mathrm{n}$ imn Dd xnsw iw.s anx". Osiris was written in both papyri with the normal signs
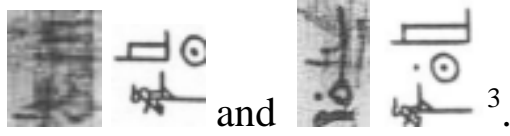

The catalogue of the British museum has a collection of hieratic Egyptian religious papyri which have also a literary character, those papyri are copies of the books of the dead in the underworld. The first part of this catalogue describes all the papyri belonging to the period commencing the $18^{\text {th }}$ dynasty and ending with the $22^{\text {nd }}$ dynasty.

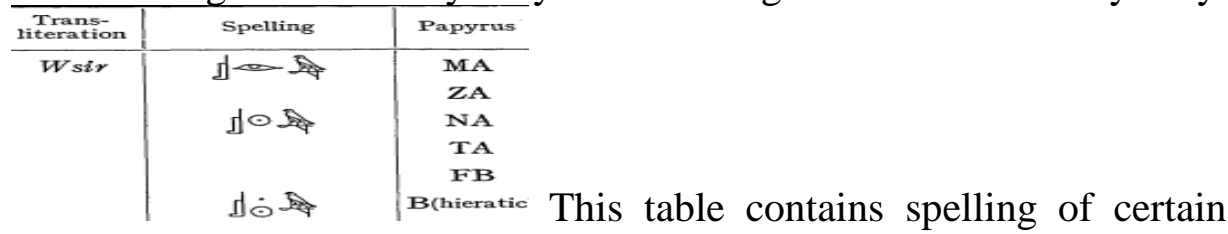

words which occurs frequently in the manuscripts in the British museum

1- Miniaci, G.: the case of the third intermediate period 'shabti-maker' of the Amun domain diamun/ padiamun and the change in conception of shabti statuettes, jstor, v.100, sage publications, 2014, p. 245-273.

2- Miniaci, G.: ibid, p.250.

3- Coenen, M.: the funerary papyri of the Bodleian library at oxford, jstor, sage publications ltd, v.86, 2000, pp.81-98. 
catalogue ${ }^{1}$. There is a limestone stela of Amenmose dating to the $18^{\text {th }}$ dynasty has a hymn contains the fullest account of the Osiris myth. Gods awarded Osiris in this myth through resurrected and making him the king of the netherworld. this myth contains most epithets of Osiris, such as " hail to you Osiris, lord of eternity, king of gods, lord of acclaim in the southern sky, one offers to him by Geb's command" ${ }^{2}$. But despite all those epithets, we didn't find Osiris as ibk here.

May be Osiris got this epithet for specific religious reason, or it was a result happened from significant changes in hieroglyphic writing occurred in the third intermediate period ${ }^{3}$.

\subsection{Osiris in funerary papyri:}

In order to transition successfully into the afterlife, Egyptians were equipped at death with protective spells. This spells expresses the rebirth of Osiris which remained central to Egyptian funerary beliefs until the Christianity period. Over time the spells transmitted from royal tombs walls to the funerary objects and papyri of private individuals ${ }^{4}$. Both men and women had access to funerary rituals. The funerary mythology of ancient Egypt involved the magical association of the deceased individual with the god Osiris from its beginning. The transformations that took place (life to death to resurrection) provided the frame by which mortal humans could follow the god into the afterlife. As the deceased could assume the role of Osiris in the afterlife ${ }^{5}$.

1- A.W. Shorter, M.A.: Catalogue of Egyptian religious papyri in the British museum, copies of the book, $p r(t)-m-h r w$, from the XVIII ${ }^{\text {th }}$ to the XXII ${ }^{\text {nd }}$ dynasty, 1- description of papyri with text, the British museum, London, 1938, pp.1-198.

2- Lichtheim, M.: ancient Egyptian literature, v.II the new kingdom, University of California Press, first edition , 2006, p.81; Moret, A.: La légende d'Osiris à l'époque thébaine d'après l'hymne à Osiris du Louvre [avec 3planches], BIFAO, 30 (1931), pp. 725-750.

3- Uranić, I.: op cit.

4- Cole, E.: op cit.

5- Cole, E.: ibid. 


\subsection{Osiris and the deceased:}

Osiris provided a model where by the effects of the rupture caused by death could be totally reversed, since that deity underwent a twofold process of resurrection. The Egyptian hoped to be revived like Osiris ${ }^{1}$. The deceased has to be judged by Osiris to pass into the next life, this make the eternal afterlife of the deceased is confirmed. In the late periods, a number of new funerary compositions were written and gathered together in "the book of traversing eternity". It includes an advice to Osiris for the protection of the deceased. A part from spell 125 is a hymn to Osiris in which the deceased is placed into the role of his protector and son. The literary and wisdom texts of the M.K. were replaced by new compositions in the late Egyptians. Hieratic became increasingly used from the TIP onward ${ }^{2}$.

\subsection{The relationship between Osiris and the deceased:}

The relationship between Osiris and the deceased depends on following not becoming. The deceased follows Osiris in two ways, he joins the retinue of Osiris's worshippers, and through the efficacy of the mummification rites which reconstitute his corporeal and social selves ${ }^{3}$. By becoming Osiris, the embalmed dead can escape the end of this world ${ }^{4}$. Burials indicate that coffins maintain the theme of becoming Osiris.

\subsection{Osiris and the funerary rituals:}

The deceased was associated with Osiris before embalming, where the best preserved and represented rituals make the deceased out to be a deity especially Osiris. Since the O.K. the elite aspired to ascend to the great god after death. The sacerdotal recitations accompanying the actions already name the deceased as the god Osiris. From the $18^{\text {th }}$ dynasty onwards, other funerary rituals were displayed, which is the

1- Smith, M.: Osiris and the deceased, UCLA, encyclopedia of Egyptology 1(1), Los Angeles, 2008, p.1-8.

2- Cole, E.: Interpretation and Authority: the social functions of translation in ancient Egypt, UCLA, 2015, p.1-325.

3- Smith, M.: Osiris and the deceased, UCLA, encyclopedia of Egyptology 1(1), Los Angeles, 2008, p.1-8.

4- Quirke, S.: Exploring religion in ancient Egypt, UK, first edition, 2015, p.145. 
journey to the sacred city of Abydos. The point of travelling there was for the deceased himself to ferry the god Osiris in his ceremonies ${ }^{1}$.

\subsection{The role of women in religious affairs in the TIP:}

Women had a great rule through the whole different stages of the Egyptian history. She had the right to rule as a queen, she had a rule in the temples entourage of the deity, and she can act freely in her money, for example, there is a papyri from the reign of Ramses $\mathrm{X}$ about a woman's will who wanted to divide her possessions between her children male and female before her death ${ }^{2}$. There are 4 papyri in this research dedicated to women, and they were all found in coffins belonging to priests of Amon. So, what is the importance of women in this period to be buried in the coffins of the priests of Amon? And what is their role to have such dedicated papyri? Women had a big role and they were treated equally to the men. They were depicted on the walls of their tombs for example; there is a seen in a fragment of the relief from the pyramid of wedjebenti in which the queen is shown smelling a lotus blossom. Women had a noticeably female physique in their representations as they were dressed in form fitting clothing ${ }^{3}$. In the pyramid texts (PT) the deceased was given a clear masculine role regardless of whether a man or a woman was involved. The queens took part in the same male cycle of rebirth established by Osiris. The scribes inserted the names of the queens where needed. The queens are given the same honor of the men, and also mentioned as wsir nn in their spells. Representations of gender in Egyptian art were idealized for both men and women and illustrated by stylized hair, clothes, body type and skin color. The images in the manuscript connected the deceased visually to a funerary context and forced scribes to consider the gender of the individual. When a manuscript was prepared specifically for a woman, the deceased was shown as a woman in elaborate dress without her husband or father. In these manuscripts woman was Isis as well as Osiris. The man wanted his wife to be presented on the document to ensure that he will reborn, but the woman didn't require her husband

1- Harold, H.: Funerary Rituals (Pharaonic Period), UCLA, encyclopedia of Egypt 1(1), 2010, p.1-16.

$$
\text { - سليم حسن: المرجع السابق، ص } 9 .
$$

3- Cole, E.: the gendered individual in funerary papyri of the Ptolemaic and roman periods, jstor, American research center in Egypt, v.49, 2013, p.205-218. 
because she took on both gender roles. a N.K. papyrus Boston MFA 1987-267 includes a vignette with a woman being led by Horus into the presence of Osiris, this papyri has masculine pronouns, for example referring to "his heart" but before the space left for the name of the deceased it is possible to read wsir nb.t pr "Osiris of the mistress of the house", the text remain grammatically masculine. Also the corpse of the woman treated like the corpse of a man and takes the Osirian form in mummification.

In the TIP the burials of elite women occurred within temple precincts, and there was a spike in female ownership of BD manuscripts. Women were mostly beneficiaries of the funerary processes created for their male relatives and were depicted on tomb walls in a stylized female form. Also in the TIP a substantial increase occurs in the number of BD papyri given to women. Women required a more complex and individualized theological response to death. This development towards increased gender specification continued into the later periods of Egyptian history ${ }^{1}$. There is a tomb from the TIP was originally designed as the burial place of 3 women of the family of high priests of the 21 dynasty. one of them was the chanters of Amon, and the other is the daughter of Pinudjem I the chief of the musicians of Amon, and the shabti box in the tomb contained 2 Osiris figures ${ }^{2}$. In the 21 dynasty in particular, a series of prominent women related to the family of the high priest of Amon in Thebes each had prepared manuscripts of their own. These women were involved in the administration of temple complexes in Thebes.

Both men and women had access to funerary rituals, as texts allowed women to take on the form of Osiris temporarily and make the journey into the afterlife. If the deceased is a woman, she took on the male attributes of Osiris, so she could assume the role of the male god while her body was prepared for the afterlife.

Although, there was a relationship between the women as god's wife to Amun and Osiris as a god of eternity. As the chapel of Osiris located to the north and northeast of the Amun-Ra temple in the Karnak temple decorated with scenes of the important priestess known as the "god's wife of Amun", and this is one of a series of structures that would be

1- Cole, E.: ibidem.

2- Miniaci, G.: op cit. 
bestowed by the "god's wives" during the TIP ${ }^{1}$. Glass in ancient Egypt appeared in the new kingdom, it was a novel and highly prized material which quickly found favor with the elite. So the women got a great role in the TIP to the extent that Neskhons the wife of Pinedjem II of the $21^{\text {st }}$ dynasty had beakers produced especially for her, which reflects the importance of the position she reached ${ }^{2}$. Another important offspring of Pinudjem I was his daughter Maetkare who took the title "god's wife of Amun"3.

1- Sullivan, E.: Karnak: Development of the temple of Amun-Ra, UCLA, Encyclopedia of Egyptology, 2010, p.18.

2- Nicholson, P.: glass working, use and discard, UCLA, encyclopedia of Egyptology, 2011, p.2.

3- Donald, R.: the oxford encyclopedia of ancient Egypt, v. I, oxford press, 2001, p.389. 


\section{$\underline{\text { Refrences }}$}

1- A.W. Shorter, M.A.: Catalogue of Egyptian religious papyri in the British museum, copies of the book, pr(t)-m-hrw, from the XVIIIth to the XXIInd dynasty, 1- description of papyri with text, the British museum, London, 1938.

2- Broekman, G.: the Theban high priestly succession in the first half of the twenty first dynasty, jstor, sage publications ltd, v.98, 2012.

3- Budge, W.: Egyptian hieroglyphic dictionary, v.1, Albemarle street, London, 1920.

4- Cerny, J. and Groll, S.: Late Egyptian Grammar, Biblical Institute press, Rome, 1975.

5- Coenen, M.: the funerary papyri of the Bodleian library at oxford, jstor, sage publications ltd, v.86, 2000.

6- Cole, E.: Interpretation \& Authority: the social functions of translation in ancient Egypt, UCLA, 2015.

7- Cole, E.: Interpretation and Authority: the social functions of translation in ancient Egypt, UCLA, 2015.

8- Erman, A. und Grapow, H.: wörterbuch der Ägyptischen Sprache, v.2, im auftrag der deutschen akademien, Berlin,1971.

9- Gardiner, A.: Egyptian Grammar, being an introduction to the study of Hieroglyphs, Griffith Institute, Ashmolean Museum Oxford, By Oxford University Press, London, Third edition, 1973.

10-Golenischeff, V.S.: Catalogue général des antiquités Égyptiennes du musée du Caire Papyrus hiératiques 1927, P.1-176.

11-Harold, H.: Funerary Rituals (Pharaonic Period), UCLA, encyclopedia of Egypt 1(1), 2010.

12- Kitchen, K.: the third intermediate period in Egypt (1100-650 BC), Warminster England, 1973.

13- Koenraad, D, et al: Hieratic, Demotic and Greek Studies and Text editions, Of Making Many Books There Is No End, Papyrologica Lugduno-Batava, Institutum Papyrologicum Universitatis Lugduno-Batavae, volumen XXXIV, 2018, P. 210 .

14- Lesko, H.: A Dictionary of Late Egyptian, I, second edition, Fall River Modern Printing Co., USA, 2002. 
15-Miniaci, G.: the case of the third intermediate period 'shabtimaker' of the Amun domain diamun/ padiamun and the change in conception of shabti statuettes, jstor, v.100, sage publications, 2014.

16-Möller, G.: Hieratische Palaographie Aegzptische Buchschirift in Ihrer Entwicklung von der Fünften Dznastie Bis Zur R ömischen Kaiseryeit, Osnabrück otto Zeller, III, 1965.

17-Rohl, D.: some chronological conundrums of the 21st dynasty, Ägypten und levanter, Austrian academy of sciences press, v.3, 1992.

18-Shoaib, W.: Aspects of rnpy in Ancient Egyptian texts, Jstor, V.48, 2012.

19- Smith, M.: Osiris and the deceased, UCLA, encyclopedia of Egyptology 1(1), Los Angeles, 2008.

20- Smith, M.: Whose Ritual? Osirian Texts and Texts written for the deceased in P. BM EA 10209: A case study, in: Liturgical Texts for Osiris and the deceased in late period and GrecoRoman Egypt, proceedings of the colloquiums at N.Y. (ISAW), 6 May 2011, and Freudenstadt, 18-21 July 2012, Wiesbaden, 2015.

21- Troche, J.: Letters to the dead, UCLA, encyclopedia of Egypt, V.1(1), 2018.

22- Uranić, I.: Book of the Dead, Papyrus Zagreb 601, Studien zur Altägyptischen Kultur, Bd. 33, 2005.

23- Verhoeven,U.: Orientalia Lovaniensia Analecta,Untersuchungen zur späthieratischen Buchschrift, uitgeverij peeters en departement orientalistiek, Leuven, 2001.

24- Vuilleumier, S.: un ritual osirien en faveur de particuliers à l'époque ptolemaique, papyrus Princeton pharaonic roll 10, Wiesbaden, 2016.

25-Winand, J.: Late Egyptian, UCLA, encyclopedia of Egyptology, university of California, Los Angeles, 2018. 